\title{
Species composition and diel variation of a butterfly taxocene (Lepidoptera, Papilionoidea and Hesperioidea) in a restinga forest at Itapuã State Park, Rio Grande do Sul, Brazil ${ }^{1}$
}

\author{
Maria O. Marchiori ${ }^{2} \&$ Helena P. Romanowski ${ }^{2}$ \\ ${ }^{1}$ Contribution number 492 of the Programa de Pós-Graduação em Biologia Animal, Instituto de Biociências, Universidade \\ Federal do Rio Grande do Sul. \\ 2 Programa de Pós-Graduação em Biologia Animal, Instituto de Biociências, Universidade Federal do Rio Grande do Sul. \\ Avenida Bento Gonçalves 9500, Prédio 43435, 91501-970 Porto Alegre, Rio Grande do Sul, Brasil. \\ E-mail: mariosti2@hotmail.com; hpromano@ufrgs.br
}

\begin{abstract}
The composition and the hourly variation of butterfly species (Lepidoptera: Papilionoidea and Hesperioidea) throughout the day and the seasons was evaluated in a 1,000 $\mathrm{m}^{2}$ patch of sandy forest (Restinga forest) on a coastal plain at Itapuã State Park ( $\left.30^{\circ} 22^{\prime} \mathrm{S}, 51^{\circ} \mathrm{O} 2^{\prime} \mathrm{W}\right)$, Viamão, Rio Grande do Sul, from July 2001 to June 2002. Butterflies were sampled by scanning and focal observations (adapted from AltmanN 1974) carried out at successive 45 minutes intervals. This methodology proved to be effective in recording the presence and activity of butterflies on a small area. A total of 108 observation hours yielded 326 butterflies from 41 species, 33 genera and five families. Nymphalidae was the most abundant family contributing with $74 \%$ of the total individuals. The most abundant species was Eunica eburnea Fruhstorfer, 1907 (Nymphalidae) with 45 individuals registered along the year. General diversity estimates were Dmg $=6.912, \mathrm{H}^{\prime}=3.012$ and $\mathrm{d}=0.138$. Although there were variations in the daily times of butterfly activity throughout the seasons, there was a general trend for higher activity during the morning period, between 9:00 and 11:45 h.
\end{abstract}

KEY WORDS. Eunica eburnea; Nymphalidae; sampling method.

RESUMO. Composição e variação ao longo do dia na taxocenose de borboletas (Lepidoptera, Papilionoidea e Hesperioidea) em uma mata de restinga no Parque Estadual de Itapuã, Rio Grande do Sul, Brasil. A composição e a variação das espécies de borboletas (Lepidoptera, Papilionoidea e Hesperioidea) ao longo dos diferentes horários do dia e das estações do ano foi avaliada em uma mancha de $1.000 \mathrm{~m}^{2}$ de mata de restinga

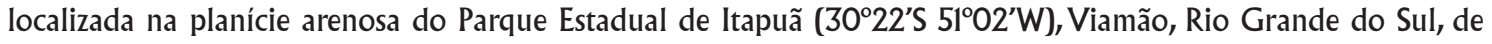
julho 2001 a junho 2002. As borboletas foram amostradas através de observações de varredura e focal (adaptadas de Altmann 1974) a intervalos sucessivos de 45 minutos cada. Esta metodologia demonstrou-se eficaz no registro da presença e atividade das borboletas em uma área de tamanho reduzido. Um total de 108 horas de observação resultou em 326 borboletas distribuídas em 41 espécies, 33 gêneros e cinco famílias. Nymphalidae foi a família mais abundante contribuindo com $74 \%$ do total de indivíduos observados. A espécie mais abundante foi Eunica eburnea Fruhstorfer, 1907 (Nymphalidae) com 45 indivíduos registrados ao longo do ano. As estimativas gerais de diversidade foram $\mathrm{Dmg}=6,912, \mathrm{H}^{\prime}=3,012$ e $\mathrm{d}=0,138$. Embora tenha sido observada variação no horário de atividade das borboletas ao longo das estações do ano, a tendência para maior atividade foi durante o período da manhã, entre 9:00 e 11:45 h.

PALAVRAS-CHAVE. Eunica eburnea; método de amostragem; Nymphalidae.

The Brazilian coastal sandy ecosystem (Restinga), which is composed by dune strips, forests, marshes and shrub vegetation, is currently threatened by intense anthropic activity. As a corollary, biological and landscape components are being progressively degraded, especially near the coast. Amidst this dev- astation, animal and plant species are eliminated, restricting biotic diversity and risking valuable genetic stock (MACIEL 1994). To accurately evaluate biodiversity conservation, it is necessary to know which species are present, as well as their biological features and possible vulnerability to environmen- 
tal changes (WiLson 1987, 1997). LeWInsohn et al. (2001) state that biological inventories are basic tools for the evaluation of biodiversity, as well as for monitoring changes in its different components, either in face of distinct environmental conditions, or in response to impacts due to natural processes or human activities.

Restingas are a peculiar and fragile ecosystem for which data of this nature is hardly available. This gap in our knowledge is particularly important for the coastal plain of Rio Grande do Sul state, southern Brazil, where this ecosystem is ubiquitous. On the margins of the Patos Lagoon and Guaíba Lake, restingas are composed of dune strips interspersed with humid lowlands and positioned along the coastline (Menegat et al. 1998). Forests characteristic of this environment are spatially distributed as patches of variable extension, disappearing completely at the extreme south of the country (WAECHTER 1985). The vegetation of these forests is low, 6-12 $\mathrm{m}$ high, and when occuring on well-drained sandy soil, a xeromorphic tendency becomes evident. Some of the trees and shrubs have numerous twisted branches with thorns and small shiny hard leaves (BRACK et al. 1998, WAECHTER \& JARENKOW 1998). The main environmental factors influencing vegetation composition are the scarcity of nutrients and water, excess heat and light and the constancy of the wind (MORENo 1961).

The insect fauna of restingas have been scarcely studied in Brazil (Lacerda et al. 1982, Maciel 1984, Monteiro \& Macedo 1990) and most of the works on populations and insect natural communities in this ecosystem were carried out in the southeastern region (Callaghan 1986, da Silva \& Nessimian 1990, Monteiro \& Macedo 1990, 2000, Monteiro 1991, Macedo et al. 1994, Monteiro \& BecKer 2002). Some of these studies mention the importance of Lepidoptera in the restinga ecosystem in terms of both their abundance and their role in ecological processes.

More recently, Monteiro et al. (2004) presented a list of butterflies and moths from the Restinga of Jurubatiba National Park ( $\left.22^{\circ} 15^{\prime} \mathrm{S} 41^{\circ} 39^{\prime} \mathrm{W}\right)$, Rio de Janeiro state, together with biological and ecological considerations. In addition, some studies recorded species of butterflies endemic to restingas. This status has been registered by Callaghan $(1977,1978)$ for the butterfly Menander felsina (Hewitson, 1863) (Lycaenidae) and by Otero \& Brown (1986) for Parides ascanius (Cramer, 1775) (Papilionidae). The latest occurs only at the coastal zone of Rio de Janeiro state and is currently threatened with extinction. For southern Brazil, no studies about butterflies in the restinga environment have been published so far.

Butterflies are considered especially useful organisms as indicators of environmental quality (BROWN 1991, KREMEN 1992, Brown \& Freitas 1999). Their taxonomy is well defined as compared to other groups of tropical insects; adults of many species can be reliably identified in the field; they have rapid life cycles and tight association with plant resources; populations are very sensitive to local weather, microclimates and light levels (Ehrlich \& Murphy 1987, Beccalloni \& Gaston 1995, Hill et al. 1995, De Vries et al. 1997, New 1997, Wood \& Gillman 1998, Brown \& Freitas 2000, Konvicka et al. 2003, Kitahara 2004). Butterflies thus make up very adequate tools for measures of environmental variation and the integrity of natural landscapes.

Precise information of temporal order is useful for environmental analyses, since animals, plants and many physical and chemical variables have daily or seasonal patterns (Brower et al. 1990). Different species of butterflies distribute their flight activities, feeding, mating and oviposition along the day differently; some species fly in the early morning and others in late afternoon, but most are active on the sunniest hours of the day (Brown 1992, Freitas et al. 2003).

Callaghan $(1977,1978)$ observed that, in the restinga forests of Rio de Janeiro, both sexes of the butterfly $M$. felsina could be found sunning in the early morning hours on the upper surfaces of leaves. Group feeding took place in the morning hours from 8:00 $\mathrm{h}$ to $11: 00 \mathrm{~h}$, and to a lesser degree in the late afternoon. He also registered that for the same species the time of oviposition was between $12: 30 \mathrm{~h}$ and $14: 00 \mathrm{~h}$ and that males position themselves on the edges of trails and clearings waiting for females, between 12:30 $\mathrm{h}$ and 15:00 h.

VANini et al. (1999) observed the timing of activity in adults of Eurema elathea (Cramer, 1777) (Pieridae) in the campus of Campinas State University, São Paulo. Activity began at about 8:00 $\mathrm{h}$ during summer and at 10:00 h during winter, having a peak between 12:00 h and 14:00 h. From 16:00 h on, activity diminished. Similarly, Ramos \& Freitas (1999) observed that adults of Heliconius erato phyllis (Fabricius, 1775) (Nymphalidae), in the Voturuá Hill, São Paulo, began their activities also at about 8:00 h during summer and 9:30 h during winter. In both studies it was clear that these times could vary widely according to the season and atmospheric conditions. In some cold winter days, the activity of both species began only after 10:30 h. In spite of the variation on the timing of activity in some butterfly populations being well known, standardized field data on times and diel activity patterns in butterfly communities are practically nonexistent. In addition to that, in the published literature of butterfly communities, there is no mention of the variation on the patterns of diel activities in a given place, latitude or vegetation type.

Adult butterflies can be sampled with baited traps or entomological nets, however, for monitoring schemes, none of these methods is completely efficient on its own (WALPole \& SHeldon 1999). Many inventories are based on the so-called "Pollard walk" technique, which consists on weekly observations along a transect route, walked in a set length of time, when the recorder makes a series of counts noting any butterflies seen within $5 \mathrm{~m}$ (Pollard et al. 1975, Pollard 1977, 1979). Studies based on this methodology offer fast estimates of species richness and abundance (WALPOLE \& SHELDON 1999, Caldas $\&$ RobBins 2003). However, it is difficult (or practically impossible) to register temporal patterns of activity of butterflies and count them at the same time using this procedure without los- 
ing information or breaking the assumptions of the technique. On the other hand, in behavioural studies, where activities are recorded in detail, inventories are not concomitantly carried out. Furthermore, there are few objective data on the impact of the variation in daily activity times of the butterflies on the results obtained in faunal inventories.

Thus, the aims of the present study were: (I) to evaluate the technique of scanning and focal sampling for butterfly studies; (II) to analyse the composition of the butterfly taxocenose and its daily activity pattern in a patch of restinga forest at Itapuã State Park, Southern Brazil and (III) to increase our knowledge of the biology of butterfly species with information on diel activity and its variation. We also hope this knowledge might help in the conservation of the lepidopteran fauna of Rio Grande do Sul state.

\section{MATERIAL AND METHODS}

Itapuã State Park (hereafter ISP) $\left(30^{\circ} 22^{\prime} \mathrm{S}, 51^{\circ} 02^{\prime} \mathrm{W}\right)$ has an area of 5,566.50 ha and is located at the municipality of Viamão, $57 \mathrm{~km}$ south from Porto Alegre, Rio Grande do Sul, Brazil (Fig. 1). According to the Köppen system, the climate in the region is subtropical humid, variety Cfa, without a dry season, and with average annual temperatures and precipitation of about $17,5^{\circ} \mathrm{C}$ and $1.300 \mathrm{~mm}$, respectively. Rainfall is evenly distributed throughout the year and summers are usually hot, with the average temperature of the hottest month higher than $22^{\circ} \mathrm{C}$ (Мота 1951). The landscape in the park is varied and influenced by a mixture of geological formations (sandbanks, granite hills, etc.). The vegetation is composed of grasslands and forest formations with a large diversity of physiognomic-floristic types at various levels of conservation (RIO GRANDE DO SUL 1997).

This study was conducted on a patch of restinga forest (hereafter PRF) with a marked presence of Myrtaceae. This patch is positioned southeastern of the Grota Hill and on the margins of the Negra Lagoon. It is $346 \mathrm{~m}$ long on the east-west axis and $75 \mathrm{~m}$ long on the north-south axis, being bounded by fields to the east, west and south, and by the Negra Lagoon to the north. Shoots with flowers were collected for identification by taxonomists of the Botany Department of the Rio Grande do Sul Federal University (UFRGS).

Monthly observations were carried out from July 2001 to June 2002, between 8:00 and 17:45 h in an area of $1.000 \mathrm{~m}^{2}$. To register butterfly species occurrence, abundance and timing of the various activities, two types of sampling protocols were used: scanning and focal observations, adapted from the methods described by ALTMANN (1974). Scanning observations consisted of a wide survey of the sampling area, in order to register all individuals locally present at each time. Focal observations consisted in observing the activity of a single individual or group of individuals during a given period of time. Activities were recorded as "flying", "resting" (sitting with open or closed wings), "feeding", "mating" and "oviposition". The hour of the day each type of activity started and finished was recorded for each individual

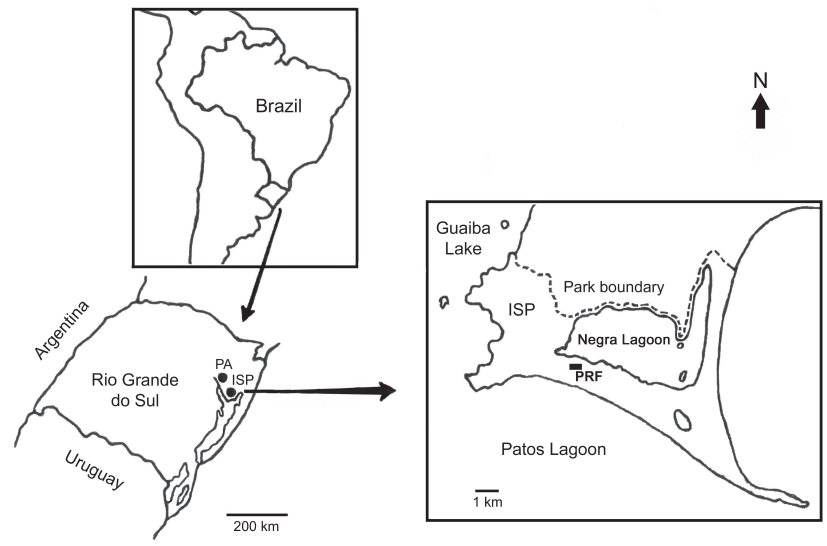

Figure 1. Map of Itapuã State Park (ISP), $30^{\circ} 22^{\prime} \mathrm{S} 51^{\circ} 02^{\prime} \mathrm{W}$, Rio Grande do Sul, Brazil, indicating the location of the patch of restinga forest (PRF). (PA) Porto Alegre.

or group of individuals that were being followed during the focal observation. The time period for each type of sampling was defined as regular intervals of 45 minutes, interspersed by 15 minutes of resting intervals. The two types of observations were carried out alternately and successively. Thus, a sampling day always started at 8:00 $\mathrm{h}$ by a scanning observation, lasting 45 minutes. This observation was followed by a 15 minutes interval and then a focal observation was carried out during $45 \mathrm{~min}$ utes followed by another 15 minutes of resting. This procedure was repeated all day long until 17:45 h.

Butterflies were recorded and if necessary for the identification, they were captured with an entomological net and whenever possible, released again. At least two individuals of each species were collected and deposited in the Lepidopteran Reference Collection of the Insect Bioecology Laboratory of the Zoology Department, UFRGS. Species identification was based on the literature (D'ABRERA 1981, 1984, 1987a, b, 1988, 1994, BROWN 1992, Tyler et al. 1994, CANALS 2000, 2003), and if necessary they were sent to specialists. Species classification followed BRowN (1992) and Freitas \& BRown (2004). The nomenclature was actualised according to LAMAs (2004).

Sampling sufficiency was analysed by the number of new species collected with the accumulating number of sampling occasions. Expected richness was estimated with Chao 1, Bootstrap, Jack-knife and Michaelis-Menten indices calculated with EstimateS, version 7.0 (Colwell 2004). Species richness was also assessed separately for each time of the day and estimators were calculated by the same program. The proportions of individuals and species per family of butterfly were compared to data available from other environments in the park (KAMINSKI et al. 2001) using Chi-square tests. To assess diversity Species Richness (S) and the indices of Margaleff (Dmg), Shannon-Wiener $\left(\mathrm{H}^{\prime}\right)$ and Berger-Parker $(\mathrm{d})$ were used (Southwood 1978, Magurran 1988, KREBS 1989). 


\section{RESULTS AND DISCUSSION}

A total of 108 hours of sampling resulted in 326 individuals of butterflies recorded. These individuals belonged to five families, 33 genera and 41 species (Tab. I).

The cumulative number of species per sampling event was ascendant until the autumn (April) (Fig. 2), stressing the need for long-term studies so that the representative taxocenoses can be thoroughly surveyed (Brown \& FreItAs 2000). The temporal extension of an inventory tends to increase the total number of species recorded, besides increasing the probability of detection of species with low population sizes (SuMMERVILLE et al. 2001); on the other hand, the proportion of "tourist" species also tends to grow in the sample (GASTON 1996) and it is generally difficult to distinguish among the two situations. Estimates of the expected richness indicate that between $74,9 \%$ and $86,7 \%$ of the species present at the sampling site during the period of study were found.

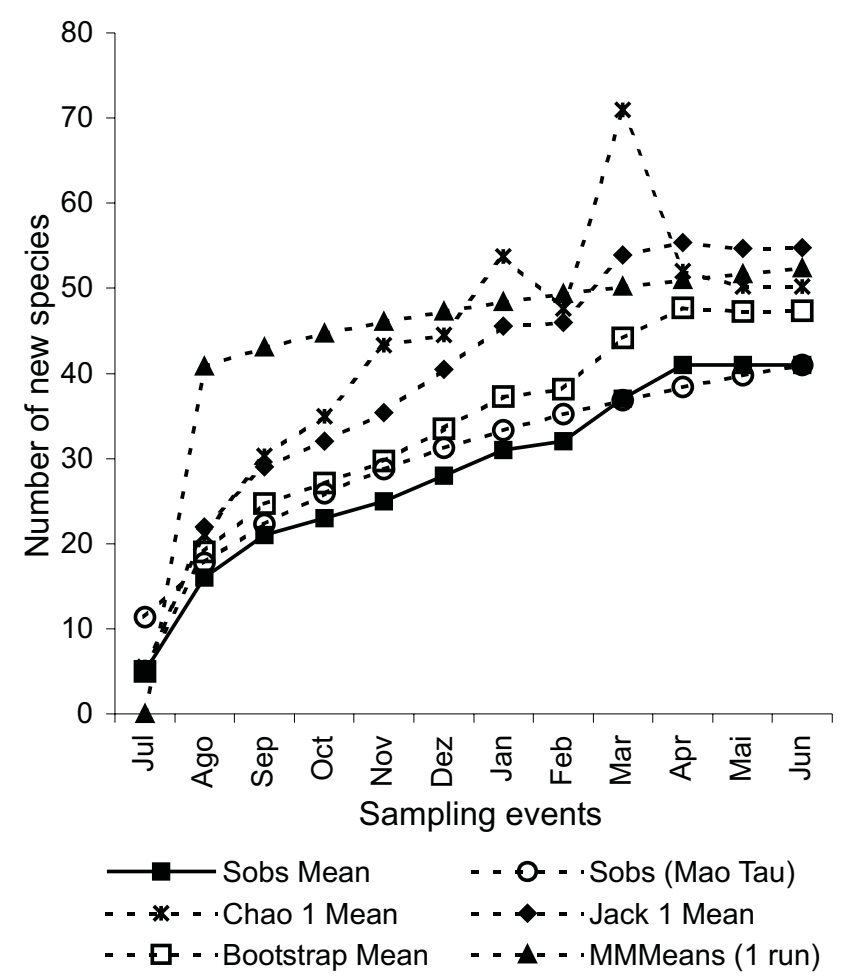

Figure 2. Species accumulation and richness estimates for 1000 $\mathrm{m}^{2}$ of restinga forest at the Itapuã State Park, Rio Grande do Sul, Brazil, from July 2001 (Jul) to June 2002 (Jun).

The Nymphalidae family represented $74 \%$ of the total number of individuals recorded, followed by Hesperiidae (17\%), Pieridae (6\%), Lycaenidae (2\%) and Papilionidae (1\%) (Fig. 3). A similar trend was observed for species richness (Fig. 4). Previous surveys in other environments of the ISP (KAMINSKI et al.
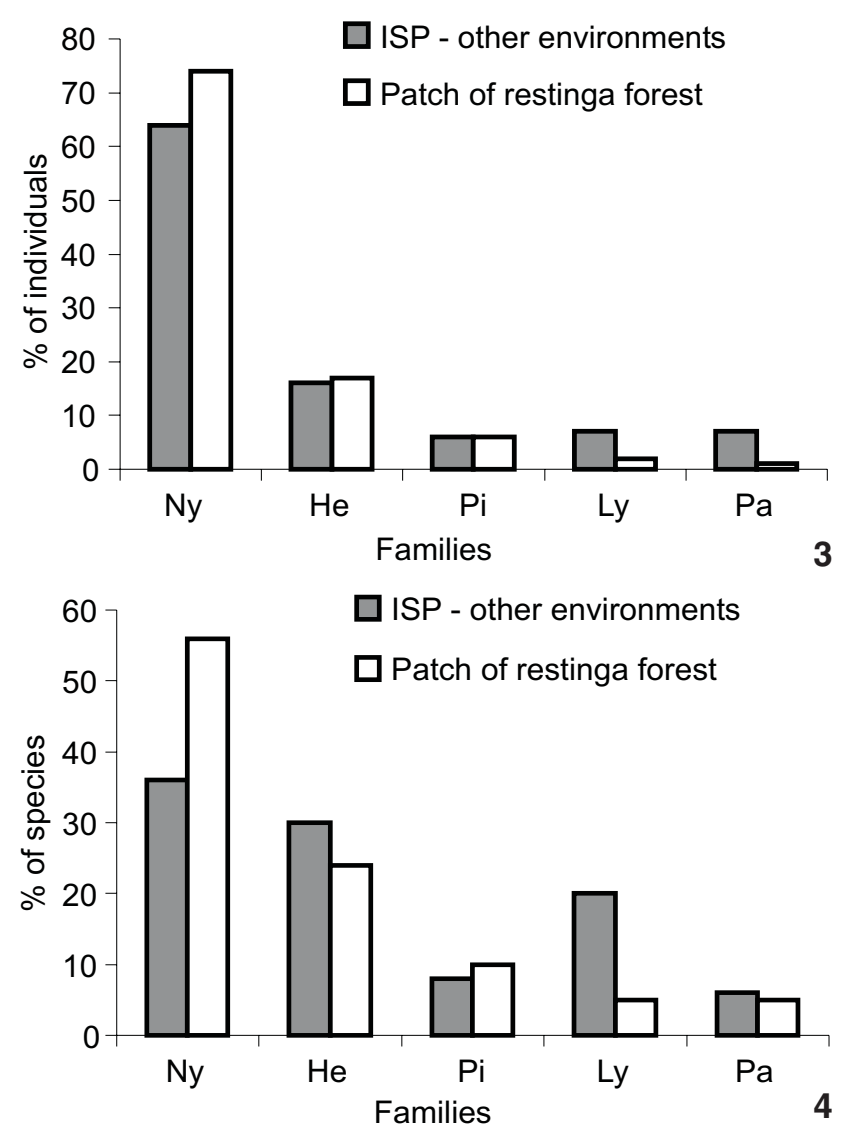

Figures 3-4. Family composition of the butterfly samples in the restinga forest $(N=326, S=41)$, from July 2001 to June 2002, and in other environments $(N=2731, S=153)$ of the Itapuã State Park (ISP), Rio Grande do Sul, Brazil. (Ny) Nymphalidae, (He) Hesperidae, (Pi) Pieridae, (Ly) Lycaenidae and (Pa) Papilionidae.

2001) showed a predominance of nymphalids and hesperiids, which was also observed in PRF. However, the family proportions differ in some aspects. In the present paper, the relative abundance of nymphalids was higher and those of lycaenids and especially papilionids were significantly lower than in other environments of the ISP (Fig. $3 ; \chi^{2}=31.20 ; \mathrm{p}<0.001 ; \mathrm{gl}=4$ ).

Regarding species richness, the proportion of nymphalids was higher and that of hesperiids and, in particular, of lycaenids was lower in our results. No statistical significance was detected in spite of these differences (Fig. $4 ; \chi^{2}=8.32 ; \mathrm{p}>0.05 ; \mathrm{gl}=4$ ). It is suggested that the disparity between sample sizes in the restinga patch $(S=41)$ and those available for other environments of the ISP ( $\mathrm{S}=153)$, as well as the dilution of the large difference presented by Lycaenidae in the analysis of the general composition could have influenced this result.

MonTEIro et al. (2004) present the only butterfly survey in a restinga environment published so far for Brazil. Between July 2001 and July 2002 they recorded 59 species of butterflies 
Table I. Species of butterflies and number of individuals recorded in $1000 \mathrm{~m}^{2}$ of restinga forest at the Itapuã State Park, Rio Grande do Sul, Brazil, from July 2001 to June 2002. (N) Number of individuals.

\begin{tabular}{|c|c|c|}
\hline & Species & $\mathrm{N}$ \\
\hline \multicolumn{3}{|l|}{ Hesperioidea } \\
\hline \multicolumn{3}{|l|}{ Hesperiidae } \\
\hline \multirow[t]{3}{*}{ Hesperiinae } & Callimormus rivera (Plötz, 1882) & 1 \\
\hline & Corticea immocerinus (Hayward, 1934) & 2 \\
\hline & Polites vibex catilina (Plötz, 1886) & 7 \\
\hline \multirow[t]{7}{*}{ Pyrginae } & Achlyodes mithridates thraso (Hübner, [1807]) & 1 \\
\hline & Pyrgus orcus (Stoll, 1780) & 6 \\
\hline & Ridens fulima Evans, 1952 & 3 \\
\hline & Urbanus procne (Plötz, 1880) & 12 \\
\hline & Urbanus simplicius (Stoll, 1790) & 15 \\
\hline & Urbanus teleus (Hübner, 1821) & 3 \\
\hline & Xenophanes tryxus (Stoll, 1780) & 4 \\
\hline \multicolumn{3}{|l|}{ Papilionoidea } \\
\hline \multicolumn{3}{|l|}{ Lycaenidae } \\
\hline \multirow[t]{2}{*}{ Riodininae } & Aricoris signata (Stichel, 1910) & 2 \\
\hline & Euselasia hygenius occulta Stichel, 1919 & 7 \\
\hline \multicolumn{3}{|l|}{ Nymphalidae } \\
\hline Apaturinae & Doxocopa laurentia (Godart, [1824]) & 3 \\
\hline \multirow[t]{2}{*}{ Biblidinae } & Eunica eburnea Fruhstorfer, 1907 & 45 \\
\hline & Hamadryas epinome (C. Felder \& R. Felder, 1867) & 3 \\
\hline Charaxinae & Zaretis itys itylus (Westwood, 1850) & 1 \\
\hline \multirow[t]{2}{*}{ Danainae } & Danaus gilippus gilippus (Cramer, 1775) & 4 \\
\hline & Danaus erippus (Cramer, 1775) & 1 \\
\hline \multirow[t]{4}{*}{ Heliconiinae } & Actinote melanisans Oberthür, 1917 & 1 \\
\hline & Dryadula phaetusa (Linnaeus, 1758) & 5 \\
\hline & Dryas iulia alcionea (Cramer, 1779) & 19 \\
\hline & Heliconius erato phyllis (Fabricius, 1775) & 28 \\
\hline Limenitidinae & Adelpha hyas (Doyère, [1840]) & 1 \\
\hline \multirow[t]{6}{*}{ Nymphalinae } & Anartia amathea roeselia (Eschscholtz, 1821) & 22 \\
\hline & Anartia jatrophae (Linnaeus, 1763) & 1 \\
\hline & Junonia evarete (Cramer, 1779) & 3 \\
\hline & Ortilia ithra (W.F. Kirby, 1900) & 28 \\
\hline & Tegosa claudina (Eschscholtz, 1821) & 18 \\
\hline & Vanessa braziliensis (Moore, 1883) & 2 \\
\hline \multirow[t]{6}{*}{ Satyrinae } & Hermeuptychia hermes (Fabricius, 1775) & 11 \\
\hline & Pampasatyrus periphas (Godart, [1824]) & 1 \\
\hline & Paryphthimoides phronius (Godart, [1824]) & 1 \\
\hline & Paryphthimoides poltys (Prittwitz, 1865) & 12 \\
\hline & Yphthimoides celmis (Godart, [1824]) & 29 \\
\hline & Yphthimoides ochracea (Butler, 1867) & 2 \\
\hline \multicolumn{3}{|l|}{ Papilionidae } \\
\hline \multirow[t]{2}{*}{ Papilioninae } & Battus polydamas polydamas (Linnaeus, 1758) & 1 \\
\hline & Heraclides anchisiades capys (Hübner, [1809]) & 1 \\
\hline \multicolumn{3}{|l|}{ Pieridae } \\
\hline \multirow[t]{4}{*}{ Coliadinae } & Eurema elathea (Cramer, 1777) & 12 \\
\hline & Eurema phiale (Cramer, 1775) & 3 \\
\hline & Phoebis neocypris (Hübner, [1823]) & 2 \\
\hline & Phoebis sennae (Linnaeus, 1758) & 3 \\
\hline Total & & 326 \\
\hline
\end{tabular}


by netting at the Restinga of Jurubatiba National Park, Rio de Janeiro state. Of these, $46 \%$ were nymphalids, $16 \%$ pierids, $14 \%$ hesperiids, $14 \%$ lycaenids and $10 \%$ papilionids. Although these proportions and the relation among the proportions differ from those registered for PRF, Nymphalidae and Papilionidae were the families with the highest and lowest number of species, respectively, on both studies. In addition, the species richness of both places was not, in general, high. Though carried out in the same year, the sampling method of the present study is not the same of that used by MonTEIro et al. (2004) and the extent this could have influenced the observed differences is not clear.

The total number of individuals observed at PRF throughout the year had two peaks, one at the end of winter (August) and another in the autumn (March-May). These peaks were strongly influenced by the high local proportion of nymphalids (Tab. II). At the sampling area, lycaenids were observed mainly in winter, the number of nymphalids was low during summer and pierids were present mainly in the autumn. Average temperatures during the sampling period were milder in winter and higher in summer when compared to the expected for those seasons (Livi 1998), and may have influenced the presence of the butterflies recorded in PRF throughout the year. Butterflies derive their heat from the sun and probably lose heat mainly by seeking shade; however, heat will tend to be lost whenever the temperature of the butterfly is above that of its surroundings (OwEN 1971) what is not likely to happen in a restinga forest during the summer. Thus it is suggested that the higher average temperature during the summer in which this study was developed may have been very important in determining the low abundances recorded throughout this season in PRF. Butterflies are probably more likely to avoid excessive heat gain in the first place (OwEN op cit.) thus, butterflies could have sought for shade in environments other than PRF where shadow, and consequently a cooler habitat, were more likely to be found.

The frequency distribution of species showed few dominant species (relative frequency above 0.1) (Fig. 5) in contrast with our experience on other kinds of environments in subtropical habitats. Besides, the recorded absolute density of these species was not, in general, noticeably high. Spring showed a higher number of species with high density (5) than winter and summer ( 3 in each season). In autumn only one species had a relative frequency above 0.1 . For all seasons, more than $70 \%$ of the recorded species had intermediate abundances (relative frequency between 0.1 and 0.01 ), with this trend clearer for summer $(82 \%)$ and winter $(81 \%)$. In autumn the highest number of species was observed, and consequently, also the highest number of rare species (relative frequency below 0.01).

The estimated indices of diversity per season (Tab. III) indicate the winter $\left(\mathrm{Dmg}=3,620, \mathrm{H}^{\prime}=2,398\right)$ as the season with the lowest diversity of butterflies, increasing towards autumn (Dmg = 5,626, $\left.\mathrm{H}^{\prime}=3,012\right)$. The Berger-Parker index of dominance reinforces what was observed in the rank-abundance curves (Fig. 5), indicating the summer $(d=0,120)$ as the season with the most equitable distribution of butterflies in the sampling area.

Table III. Number of individuals, species richness and indices of diversity and dominance per season of the year for the butterflies recorded in $1000 \mathrm{~m}^{2}$ of restinga forest at the Itapuã State Park, Rio Grande do Sul, Brazil, from July 2001 to June 2002. (N) Number of individuals, (S) Species richness, (Dmg) Margalef, $\left(\mathrm{H}^{\prime}\right)$ ShannonWiener and (d) Berger-Parker.

\begin{tabular}{lccccc}
\hline & Winter & Spring & Summer & Autumn & Total \\
\hline $\mathrm{N}$ & 63 & 68 & 50 & 145 & 326 \\
$\mathrm{~S}$ & 16 & 19 & 17 & 29 & 41 \\
Dmg & 3,620 & 4,266 & 4,090 & 5,626 & 6,912 \\
$\mathrm{H}^{\prime}$ & 2,398 & 2,434 & 2,724 & 3,012 & 3,012 \\
$\mathrm{~d}$ & 0,238 & 0,206 & 0,120 & 0,145 & 0,138 \\
\hline
\end{tabular}

Eunica eburnea Fruhstorfer, 1907 (Nymphalidae), with a total of 45 individuals observed (Tab. I), was the most abundant species in PRF. The most abundant species per season were all Nymphalidae: E. eburnea (24\%) during winter, Ortilia ithra (W.F. Kirby, 1900) (21\%) during spring, Dryas iulia alcionea (Cramer, 1779) (12\%) during summer and Yphthimoides celmis (Godart, [1824]) (15\%) during autumn, with 15, 14, 6 and 21 individuals respectively.

Table II. Number of individuals recorded per butterfly family in $1000 \mathrm{~m}^{2}$ of restinga forest at the Itapuã State Park, Rio Grande do Sul, Brazil, from July 2001 to June 2002.

\begin{tabular}{|c|c|c|c|c|c|c|c|c|c|c|c|c|}
\hline \multirow{2}{*}{ Families } & \multicolumn{12}{|c|}{ Months } \\
\hline & Jul & Ago & Sep & Oct & Nov & Dez & Jan & Feb & Mar & Apr & Mai & Jun \\
\hline Nymphalidae & 11 & 37 & 22 & 17 & 11 & 9 & 9 & 16 & 35 & 39 & 29 & 6 \\
\hline Hesperiidae & 1 & 3 & 8 & 1 & 4 & 7 & 4 & 2 & 9 & 7 & 8 & \\
\hline Pieridae & & & & & 1 & & 1 & 2 & 3 & 9 & 4 & \\
\hline Lycaenidae & 2 & 3 & 1 & 1 & & & & & & 2 & & \\
\hline Papilionidae & & & 1 & 1 & & & & & & & & \\
\hline Total & 14 & 43 & 32 & 20 & 16 & 16 & 14 & 20 & 47 & 57 & 41 & 6 \\
\hline
\end{tabular}

Revista Brasileira de Zoologia 23 (2): 443-454, junho 2006 

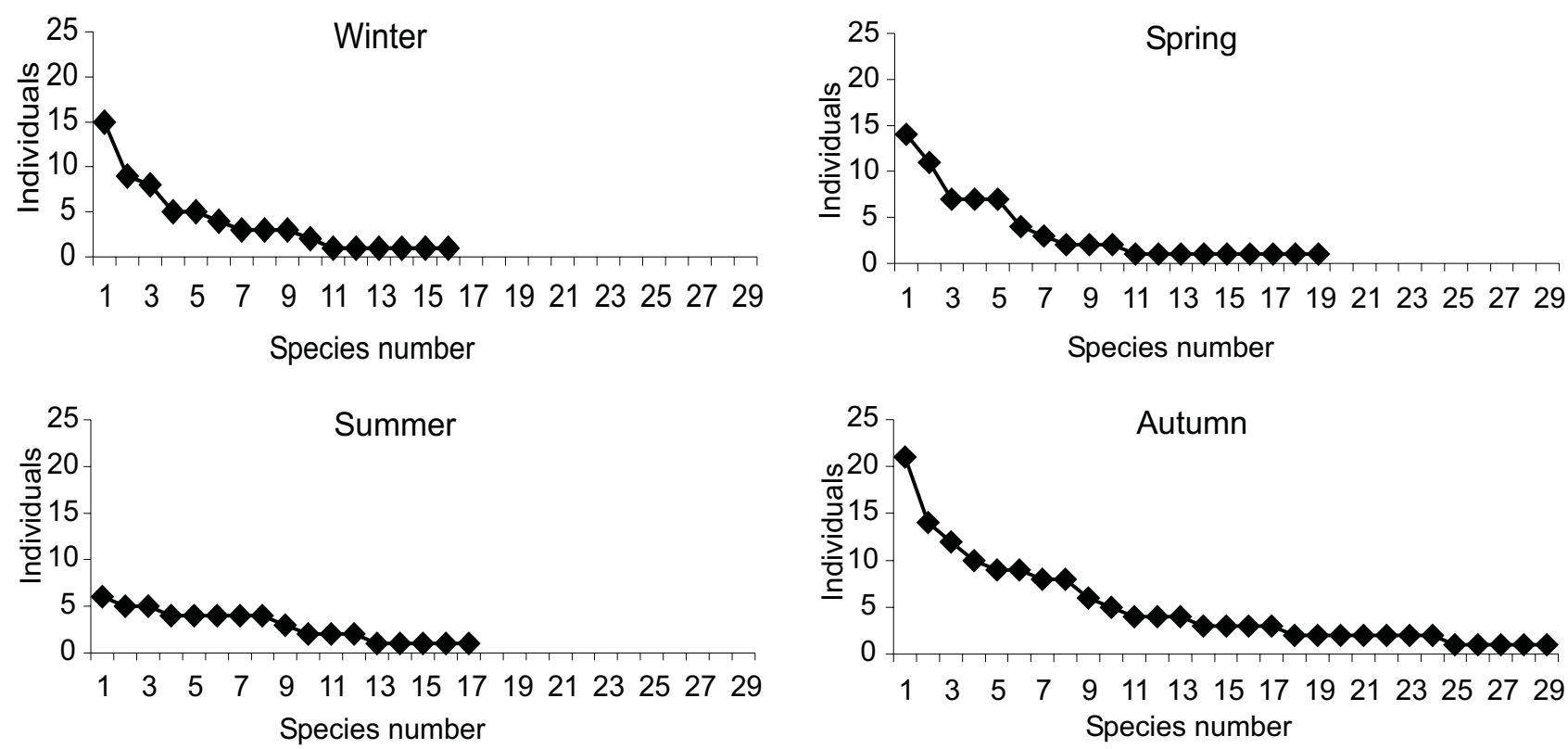

Figure 5. Rank-abundance distribution of the butterfly species per season of the year in $1000 \mathrm{~m}^{2}$ of restinga forest at the Itapuã State Park, Rio Grande do Sul, Brazil, from July 2001 to June 2002.

Eunica eburnea is a very common butterfly with a wide distribution in Brazil. It can occur both in primary and secondary vegetation, being attracted by fermenting fruits, sap and vertebrate excrements, as are species belonging to the genus Yphthimoides, quite common in open and hot environments. Dryas iulia alcionea and O. ithra feed on flowers and generally occur in naturally or anthropically disturbed environments (Brown 1992). The high abundance of O. ithra during spring seems to be related to flowering of Senecio brasiliensis Bak., an Asteraceae that seemed to be appreciated by this species during the months of September and October.

The analysis of abundance by hourly periods, throughout the whole year showed that the higher number of individuals was observed at about 11:00 $\mathrm{h}(\mathrm{N}=79)$. There was variation in the hours of higher abundance and richness throughout the seasons (Fig. 6; $\chi^{2}=97.95$ and 36.10, respectively; $\mathrm{p}<0.001 ; \mathrm{gl}=27$ ). In the winter the number of butterflies increased next to midday, when temperatures were higher, and there were no individuals recorded for the first and last sampling periods, 8:008:45 $\mathrm{h}$ and 17:00-17:45 $\mathrm{h}$, respectively. In the spring, butterflies were observed in the sampling area from the first hours of and mostly in the morning, with peaks at about 9:00 and 11:00 h. After 11:45 h, the number of individuals decreased towards the end of the afternoon. During summer there was a more equitable distribution, both for species and individuals, along the whole day. Still, activity was higher than expected in the early morning and after the hottest hours of the day. This tendency continued through autumn, but with a marked increase in abundance of individuals and species richness. In spite of the varia- tions among the seasons explained above, there was generally a tendency for more butterflies in the restinga patch during the morning time.

The most abundant family, Nymphalidae, had individuals present in PRF at almost all times of the day. The individuals of the other families seemed to concentrate more in the morning and early afternoon. Concerning species richness per family, the same trend was observed, i.e., most species of nymphalids were present almost all times of the day, whereas the species of the other families concentrate in the morning an early afternoon. However, the extent to which this result is due to the low proportions of Pieridae, Lycaenidae and Papilionidae registered in the sampling area, is not clear.

The assessment of species richness by time of the day showed that $95 \%$ of the species could be observed until 13:45 h. Only two species were not recorded before 13:45 h: Doxocopa laurentia (Godart, [1824]) (Nymphalidae) with three individuals observed at 14:00 $\mathrm{h}$ and Aricoris signata (Stichel, 1910) (Lycaenidae) with two individuals registered at 15:00 h. Trends of the estimators for richness also indicate almost no return in additional species for sampling after 13:45 $\mathrm{h}$ under the conditions this research was carried out.

Because many of the 41 species of butterflies observed occurred at low densities, detailed analyses are presented for the five most abundant species, all Nymphalidae: E. eburnea, $Y$. celmis, H. erato phyllis, O. ithra and D. iulia alcionea.

Eunica eburnea occurred all year long, mainly between 9:00 and 12:00 h. From August to April it did not occur between 12:00 and 13:00 h. Between 14:00 and 18:00 h this but-

Revista Brasileira de Zoologia 23 (2): 443-454, junho 2006 

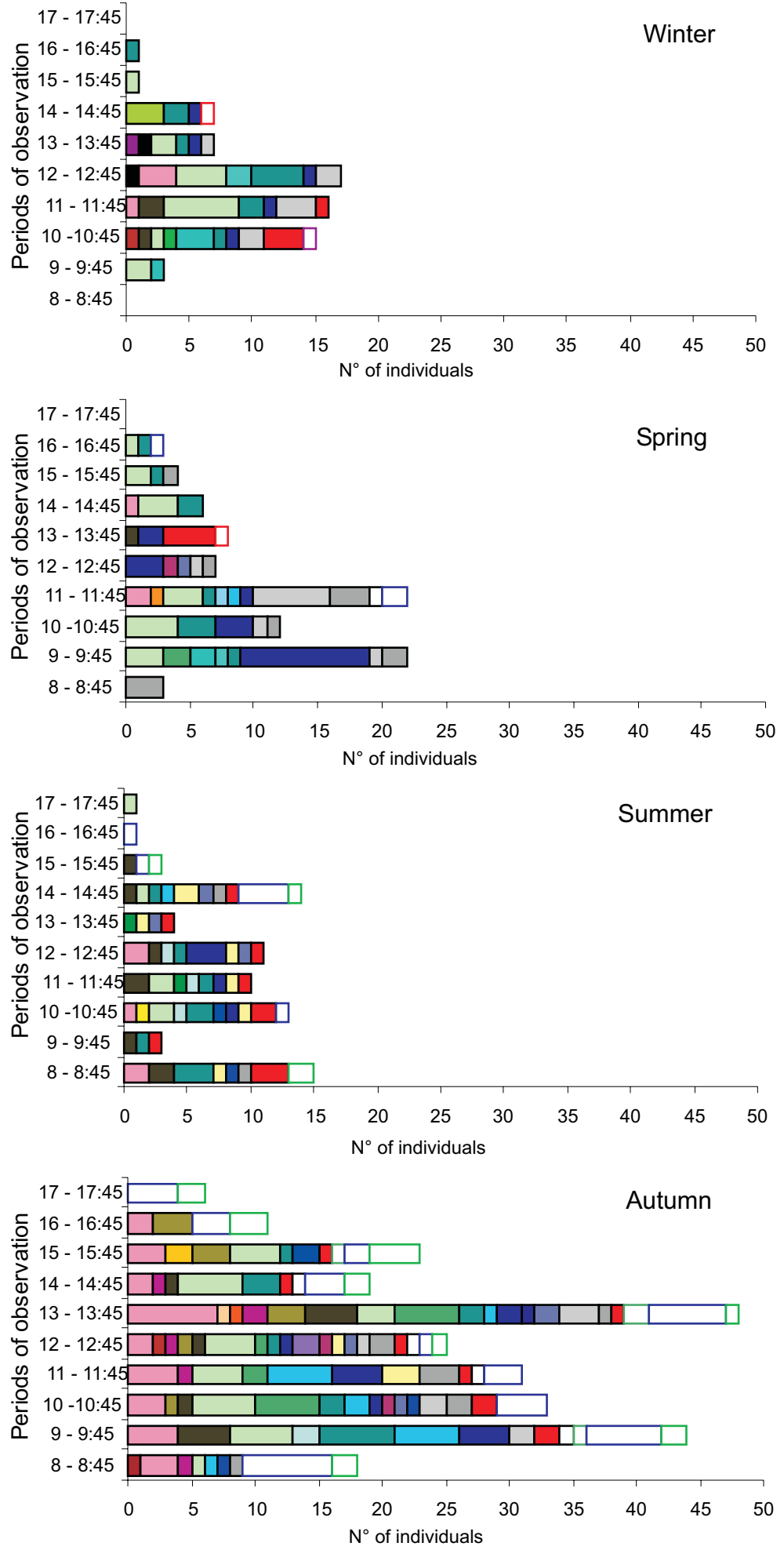

Legend for colors and respective species

Achlyodes mithridates thraso Actinote melanisans Adelpha hyas Anartia amathea roeselia Anartia jatrophae Aricoris signata Battus p. polydamas Callimormus rivera Corticea immocerinus Danaus g. gilippus Danaus erippus Doxocopa laurentia Dryadula phaetusa Dryas iulia alcionea Eunica eburnea Eurema elathea Eurema phiale Euselasia hygenius occulta Hamadryas epinome Heliconius erato phyllis Heraclides anchisiades capys Hermeuptychia hermes Junonia evarete Ortilia ithra Pampasatyrus periphas Paryphthimoides phronius Paryphthimoides poltys Phoebis neocypris Phoebis sennae Polites vibex catilina Pyrgus orcus Ridens fulima Tegosa claudina Urbanus procne Urbanus simplicius Urbanus teleus Vanessa braziliensis Xenophanes tryxus Yphthimoides celmis Yphthimoides ochracea Zaretis itys itylus

Figure 6. Frequency distribution of all butterfly species throughout the hours of the day per season of the year recorded in $1000 \mathrm{~m}^{2}$ of restinga forest at the Itapuã State Park, Rio Grande do Sul, Brazil, from July 2001 to June 2002.

Revista Brasileira de Zoologia 23 (2): 443-454, junho 2006 


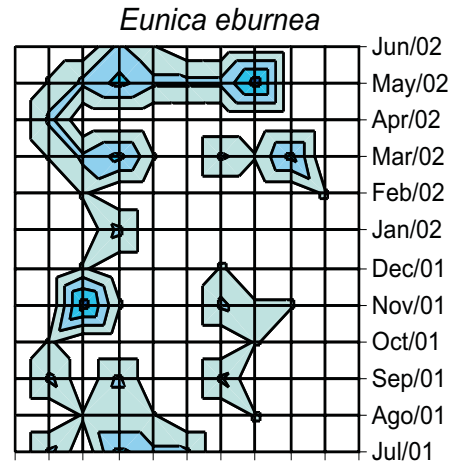

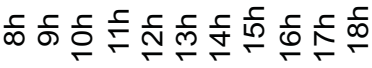

Times of the day

Heliconius erato phyllis

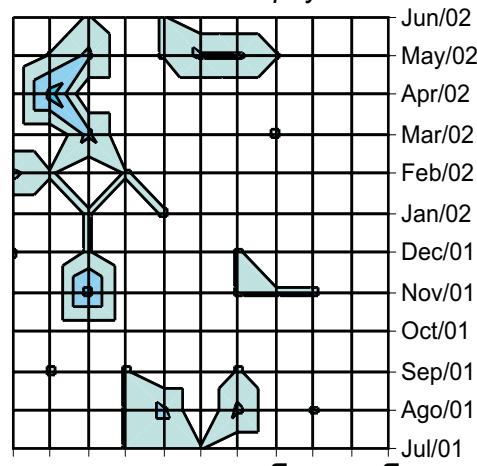

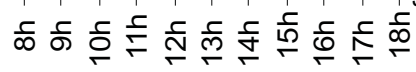

Times of the day

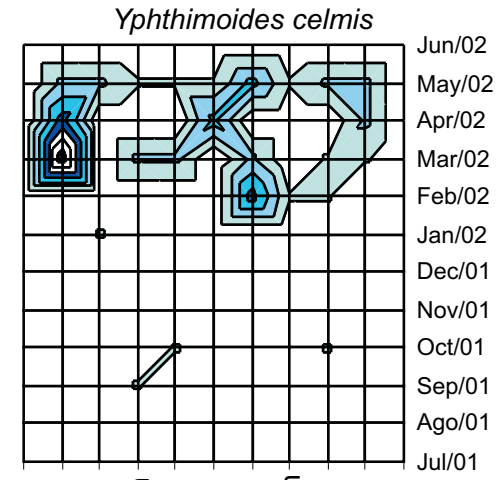

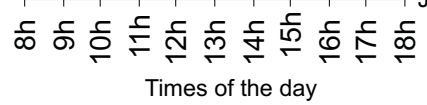

Ortilia ithra

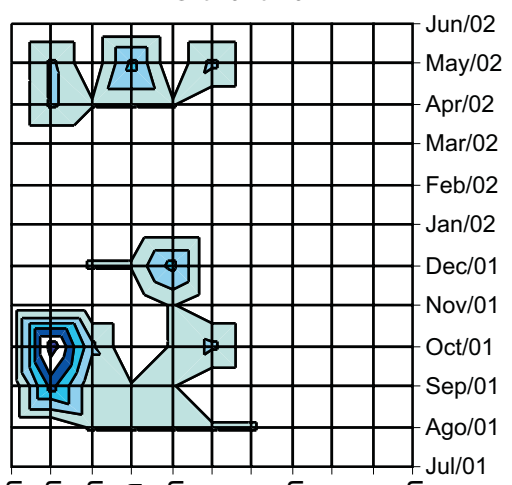

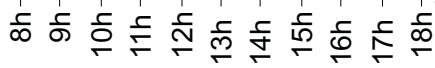

Times of the day

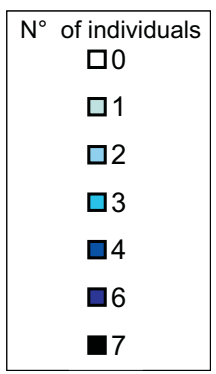

Dryas iulia alcionea

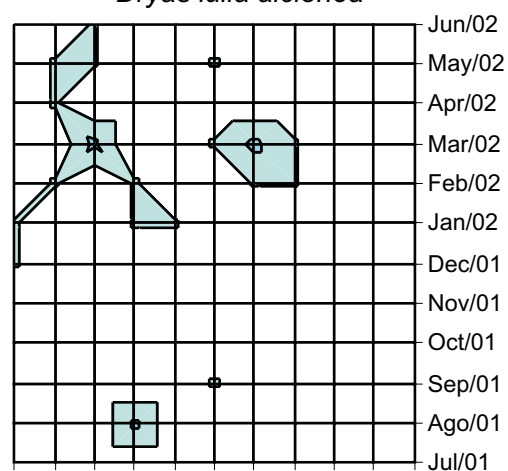

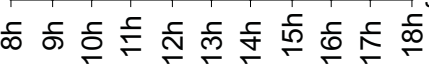

Times of the day

Figures 7-11. Density of the most abundant butterflies for the times of the day and of the year in $1000 \mathrm{~m}^{2}$ of restinga forest at the Itapuã State Park, Rio Grande do Sul, Brazil, from July 2001 to June 2002.

terfly was present at PRF only in spring and autumn months. Higher abundance was observed at about 10:00 $\mathrm{h}$ in November and at about 15:00 h in May (Fig. 7).

Yphthimoides celmis occurred mainly from February to May. It was observed at the sampling area all day long. Its higher abundance was recorded at about 14:00 h in February and at about 9:00 h in March (Fig. 8).

Heliconius erato phyllis, like E. eburnea, was present in the sampling area throughout the whole year and had a tendency to occur in the morning, between 8:00 and 12:00 h. During winter, however, its presence was recorded only from 11:00 h on. Its maximum abundance was recorded at about 10:00 $\mathrm{h}$ in November and at about 9:00 h in April (Fig. 9).

Ortilia ithra was observed at the sampling area only till 14:00 h, with maximum abundance at about 9:00 h in October. Its occurrence in PRF was recorded from August to December and from April to May (Fig. 10).

Dryas iulia alcionea was observed in August predominantly at about 11:00 h. From October to December its presence was not registered at PRF. From January on it was observed mainly in the morning, from 8:00 to $12: 00 \mathrm{~h}$, but it also occurred between 13:00 and 15:00 h in February and March (Fig. 11).

Only three out of the five types of activity were registered: flying, resting and feeding. There were no records of mating or oviposition for any butterfly species observed in the sampling area and period.

Feeding was observed in a few occasions. In addition to O. ithra, Tegosa claudina (Eschscholtz, 1821) (Nymphalidae) was also observed feeding on flowers of Senecio brasiliensis. Both were registered foraging from 9:00 to 12:00 $\mathrm{h}$ in September. In October both were registered feeding on S. brasiliensis from 9:00 to $10: 30 \mathrm{~h}$ and only $T$. claudina at about 15:00 h. One individual of Urbanus simplicius (Stoll, 1790) (Hesperiidae) was observed foraging on flowers of Vitex megapotamica (Spreng.) Mold. (Verbenaceae) from 11:00 to 11:15 h in December. In January, at about 16:30 h, two Y. celmis were recorded feeding on fermented fruits of Hexaclamys edulis (Berg) Kausel et Legr (Myrtaceae), a characteristic shrub of restinga habitat. In March,

Revista Brasileira de Zoologia 23 (2): 443-454, junho 2006 
one individual of D. iulia and two of $H$. erato phyllis were observed feeding on flowers of Lantana camara L. (Verbenaceae), from 9:40 to 10:25 and from 10:00 to 10:15, respectively.

The period of higher flight activity for most butterflies was between 9:00 and 11:45 h. In observations for different diurnal lepidopterans in southeastern Brazil (CALLAGHAN 1977, 1978, VANINI et al. 1999, Ramos \& Freitas 1999), the higher activity period was between 11:00 and 14:00 h, either in terms of flight, court, oviposition or feeding. On the other hand, BRown (1972) mentions that, in very warm areas of tropical plains, the heat leads butterflies to inactivity between 11:00 and 14:30 h. During our sampling months, the average temperatures were higher than usual for the period from August 2001 to March 2002. At the patch of restinga forest this study was carried out, the vegetation is low, the soil is sandy, and exposure to solar radiation is intense. Temperatures could have had their effect amplified throughout the day, as the soil heats up due to solar incidence, especially during summer months. Therefore, conditions from 13:00 $\mathrm{h}$ on could be too harsh and dry for the activity of most butterflies at this place. As in the studies cited above, it was observed that during winter months butterfly activity began later and ended sooner than in the summer, spring or autumn.

This pioneer evaluation of the presence and diel variation of butterflies on the sampling area was made possible through the adaptation of the methodology described in Altmann (1974), using scanning and focal observations. The methodology proved to be very useful and provided a novel approach to the assessment of the butterfly community. Scanning observations, in regular intervals of 45 minutes, were effective in carrying out the species survey, and the focal observations were important for following the peculiar activities of each individual or group of individuals.

The present study aimed to broaden the knowledge on the lepidopterofauna of Rio Grande do Sul, especially in restinga forests and in regard to the timing of activities. Generally, most of the species present throughout the four seasons showed a tendency to fly in the morning. Future surveys involving restinga habitat, especially under hot weather, should take this fact into consideration. It would be interesting to verify if the patterns observed in the present study will still hold for years in which winter and summer temperatures are not as high as those reported here. The use of this same sampling methodology for other types of environment shall be crucial to evaluate variation in patterns and to allow comparisons among the different vegetation types of Rio Grande do Sul.

\section{ACKNOWLEDGMENTS}

We are grateful to Fabiana de Camargo for helping during field work and to Cristiano A. Iserhard and Lucas Kaminski for the incentive along the present study. Special thanks to André V.L. Freitas (UNICAMP) and Olaf H.H. Mielke (UFPR) for the confirmation of the identity of several species. We are also grateful to the anonymous reviewer, to André V.L. Freitas and to Milton Mendonça Jr. for their critical review and relevant suggestions. We thank Jane Vasconcellos and Jan K.F. Mahler Jr. for the access to the Itapuã State Park. This work was supported by a grant from CAPES to M.O. Marchiori, by a grant from $\mathrm{CNPq}$ to H.P. Romanowski and partially also by $\mathrm{CNPq}$ through the Process 478787/2001-4.

\section{REFERENCES}

Altmann, J. 1974. Observational study of behavior: sampling methods. Behavior, Leiden, 49 (3-4): 227-267.

Beccalloni, G.W. \& K.J. Gaston. 1995. Predicting species richness of Neotropical forest butterflies: Ithomiinae (Lepidoptera: Nymphalidae) as indicators. Biological Conservation, Essex, 71 (1): 77-86.

Brack, P.; R.S. Rodrigues; M. Sobral \& S.L.C. Leite. 1998. Árvores e arbustos na vegetação natural de Porto Alegre, Rio Grande do Sul, Brasil. Iheringia, Série Botânica, Porto Alegre, 51 (2): 139-166.

Brower, J.E.; J. Zar \& C. von Ende. 1990. Field and laboratory methods for general ecology. Dubuque, W.C. Brown, $3^{\text {rd }}$ ed., 237p.

BRown, K.S. 1972. Maximizing daily butterfly counts. Journal of the Lepidopterists Society, Los Angeles, 26 (3): 183-196.

BRown, K.S. 1991. Conservation of Neotropical Environments: insects as indicators, p. 350-404. In: N.M. Collins \& J.A. Thomas (Eds). The conservation of insects and their habitats. London, Academic Press, XVIII+450p.

BRown, K.S. 1992. Borboletas da Serra do Japi: diversidade, hábitats, recursos alimentares e variação temporal, p. 142187. In: L.P. Morellato (Ed.). História Natural da Serra do Japi: ecologia e preservação de uma área florestal no sudeste do Brasil. São Paulo, UNICAMP, 321p.

Brown, K.S. \& A.V.L. Freitas. 1999. Lepidoptera, p. 225-245. In: C.R.F. Brandão \& E.M. Cancello (Eds). Biodiversidade do Estado de São Paulo, Brasil. Invertebrados Terrestres. São Paulo, FAPESP, XVI+279p.

Brown, K.S. \& A.V.L. Freitas. 2000. Atlantic Forest Butterflies: indicator for landscape conservation. Biotropica, Washington, 32 (4b): 934-956.

Caldas, A. \& R.K. Robbins. 2003. Modified Pollard transects for assessing tropical butterfly abundance and diversity. Biological Conservation, Essex, 110 (2): 211-219.

Callaghan, C.J. 1977. Studies on restinga butterflies. I. Life cycle and immature biology of Menander felsina (Riodinidae), a myrmecophilous metalmark. Journal of the Lepidopterists Society, Los Angeles, 31 (3): 173-181.

Callaghan, C.J. 1978. Studies on restinga butterflies. II. Notes on the population structure of Menander felsina (Riodinidae). Journal of the Lepidopterists Society, Los Angeles, 32 (1): $37-48$.

Callaghan, C.J. 1986. Restinga butterflies: biology of Synargis brennus (Stichel) (Riodinidae). Journal of the Lepidopterists Society, Los Angeles, 40 (2): 93-96. 
Canals, G.R. 2000. Mariposas Bonaerenses. Buenos Aires, L.O.L.A., 347p.

Canals, G.R. 2003. Mariposas de Misiones. Buenos Aires, L.O.L.A., 492p.

Colwell, R.K. 2004. EstimateS: Statistical estimation of species richness and shared species from samples. Version 7.0. User's guide and application. Available in the World Wide Web at: http://purl.oclc.org/estimates [access in 11.X.2004]

D'Abrera, B. 1981. Butterflies of the Neotropical Region. Part I. Papilionidae \& Pieridae. Victoria, Hill House, XIV+172p.

D'Abrera, B. 1984. Butterflies of the Neotropical Region. Part II. Danaidae, Ithomidae, Heliconidae \& Morphidae. Victoria, Hill House, XII+210p.

D'Abrera, B. 1987a. Butterflies of the Neotropical Region. Part III. Brassolidae, Acraeidae \& Nymphalidae (partim). Victoria, Hill House, IX+139p.

D'Abrera, B. 1987b. Butterflies of the Neotropical Region. Part IV. Nymphalidae (partim). Victoria, Hill House, XV+150p.

D'Abrera, B. 1988. Butterflies of the Neotropical Region. Part V. Nymphalidae (conc.) \& Satyridae. Victoria, Hill House, IX+197p.

D'Abrera, B. 1994. Butterflies of the Neotropical Region. Part VI. Riodinidae. Victoria, Hill House, IX+216p.

DA Silva, E.R. \& J.L. Nessimian. 1990. A new species of genus Parapoinx Hübner, 1826 (Lepidoptera: Pyralidae: Nymphalinae) from Rio de Janeiro state, Brasil. Revista Brasileira de Biologia, São Carlos, 50 (2): 491-495.

De Vries, P.J.; D. Murray \& R. Lande. 1997. Species diversity in vertical, horizontal, and temporal dimensions of a fruitfeeding butterfly community in an Ecuadorian rainforest. Biological Journal of the Linnean Society, London, 62 (3): 343-364.

Ehrlich, P.R. \& D.D. Murphy. 1987. Conservation lessons from longterm studies of checkerspot butterflies. Conservation Biology, Boston, 1: 122-131.

Freitas, A.V.L. \& K.S. Brown. 2004. Phylogeny of the Nymphalidae (Lepidoptera). Systematic Biology, Washington, 53 (3): 1-25.

Freitas, A.V.L.; R.B. Francini \& K.S. Brown. 2003. Insetos como indicadores ambientais, p. 125-151. In: L. CULLEN JR.; R. RUDRAN \& C. Valladares-Padua (Eds). Métodos de estudos em biologia da conservação e manejo da vida silvestre. Curitiba, UFPR, Fundação O Boticário de Proteção à Natureza, 665p.

GASTON, K.J. 1996. Biodiversity. A biology of numbers and difference. Oxford, Blackwell Science, 396p.

Hill J.K.; K.C. Hammer; L.A. Lance \& W.M.T. Banham. 1995. Effects of selective logging on tropical forest butterflies on Buru, Indonesia. Journal of Applied Ecology, Oxford, 32: 754760 .

Kaminski, L.A.; A.A. Schantz; E.C. Teixeira; C.A. Iserhard \& H.P. Romanowski. 2001. Lista preliminar de espécies de borboletas do Parque Estadual de Itapuã, RS, p. 196-201. In: A. BAGER (Ed.). Primeiro Simpósio de Áreas Protegidas. Pelotas,
Educat, 234p.

Kitahara, M. 2004. Butterfly community composition and conservation in and around a primary woodland of Mont Fuji, central Japan. Biodiversity and Conservation, London, 13 (5): 917-942.

Konvicka, M.; M. Maradova; J. Benes; Z. Fric \& P. KepKa. 2003. Uphill shifts in distribution of butterflies in the Czech Republic: effects of changing climate detected on a regional scale. Global Ecology and Biogeography, Oxford, 12 (5): 403-410.

Krebs, C.J. 1989. Ecological Methodology. New York, Harper and Row, 654p.

Kremen, C. 1992. Assessing the indicator properties of species assemblages for natural areas monitoring. Ecological Applications, Washington, 2 (2): 203-217.

Lacerda, L.D.; D.S.D. Araújo \& N.C. Maciel. 1982. Restingas Brasileiras: uma bibliografia. Rio de Janeiro, FUJB, 55p.

LAmAs, G. (Ed.). 2004. Atlas of Neotropical Lepidoptera. Checklist: Part 4A. Hesperioidea \& Papilionoidea. Gainesville, Scientific Publishers, XXXVI + 439p.

Lewinsohn, T.M.; P.I.K.L. Prado \& A.M. Almeida. 2001. Inventários bióticos centrados em recursos: insetos fitófagos e plantas hospedeiras, p. 174-189. In: B.F.S. DiAs \& I. GARAY (Eds). Conservação da biodiversidade em ecossistemas tropicais: avanços conceituais e revisão de novas metodologias de avaliação e monitoramento. Petrópolis, Vozes, 430p.

Livi, F.P. 1998. Elementos do clima: o contraste de tempos frios e quentes, p. 73-78. In: R. Menegat; M.L. Porto; C.C. Carraro \& L.A.D. Fernandes (Eds). Atlas Ambiental de Poro Alegre. Porto Alegre, UFRGS, 237p.

Macedo, M.V.; A.M. Almeida; C.R. Teixeira; M.C.P. Pimentel \& R.F. Monteiro. 1994. Entomofauna associada a duas espécies de Senna (Leguminosae) em restingas fluminenses: considerações sobre interações e comportamento, p. 204-209. In: Terceiro Simpósio de Ecossistemas da Costa Brasileira: subsídios a um gerenciamento ambiental. Serra Negra, ACIESP, vol. 3, 358p.

Maciel, N.C. 1984. Fauna das restingas do estado do Rio de Janeiro: levantamento histórico, p. 277-284. In: L.D. LACERDA; D.S.D. Araújo; R. Cerqueira \& B. Turce (Eds). Restingas: origem, estrutura e processos. Niterói, CEUFF, 477p.

Maciel, N.C. 1994. Fauna da restinga: avanços no conhecimento, p. 249-257. In: Terceiro Simpósio de Ecossistemas da Costa Brasileira: subsídios a um gerenciamento ambiental. Serra Negra, ACIESP, vol. 3, 358p.

MaguRRAN, A. 1988. Ecological diversity and its measurements. Cambridge, University Press, 179p.

Menegat R.; M.L. Porto; C.C. Carraro \& L.A.D. Fernandes. 1998. A dinâmica das restingas, p. 91-92. In: R. Menegat; M.L. Porto; C.C. Carraro \& L.A.D. Fernandes (Eds). Atlas Ambiental de Poro Alegre. Porto Alegre, UFRGS, 237p.

MonteIro, R.F. 1991. Cryptic larval polychromatism in Rekoa marius Lucas and $R$. palegon Cramer (Lycaenidae: Thecline). 
Journal of Research on the Lepidoptera, Arcadia, 29 (12): 77-84.

Monteiro, R.F. \& M.V. Macedo. 1990. Perspectivas do estudo de ecologia de insetos em restingas, p. 326-351. In: Segundo Simpósio de Ecossistemas da Costa Sul e Sudeste Brasileira: estrutura, função e manejo. Águas de Lindóia, ACIESP, vol. 3, 429p.

Monteiro, R.F. \& M.V. Macedo. 2000. Flutuação populacional de insetos fitófagos em restinga, p.77-88. In: F.A. Esteves \& L.D. LACERDA (Eds). Ecologia de Restingas e Lagoas Costeiras. Macaé, NUPEM/UFRJ, 446p.

Monteiro, R.F. \& V.O. BecKer. 2002. A new Sigelgaita Heinrich (Lepidoptera, Pyralidae, Phycitinae) feeding on cacti in Brazil. Revista Brasileira de Zoologia, Curitiba, 19 (Supl. 1): 229-304.

Monteiro, R.F.; A.F. Esperanço; V.O. Becker; L.S. Otero; E.V. Herkenhoff \& A. Soares. 2004. Mariposas e borboletas na Restinga de Jurubatiba, p. 143-164. In: C.F.D. RоснA; F.A. Esteves \& F.R. Scarano (Eds). Pesquisas de longa duração na Restinga de Jurubatiba: ecologia, história natural e conservação. São Carlos, RiMa, 376p.

Moreno, J.A. 1961. Clima do Rio Grande do Sul. Porto Alegre, Secretaria da Agricultura, 42p.

Mota, F.S. 1951. Estudos do clima do estado do Rio Grande do Sul, segundo o sistema de W. Köppen. Revista Brasileira de Geografia, Rio de Janeiro, 13 (2): 275-284.

New, T.R. 1997. Are Lepidoptera an effective "umbrela group" for biodiversity conservation? Journal of Insect Conservation, Dordrecht, 1 (1): 5-12.

Otero, L.S. \& K.S. Brown. 1986. Biology and ecology of Parides ascanius (Cramer, 1775) (Lep., Papilionidae), a primitive butterfly threatened with extinction. Atala 10-12: 1-16.

Owen, D.F. 1971. Tropical butterflies. London, Oxford University Press, 214p.

Pollard, E. 1977. A method for assessing changes in the abundance of butterflies. Biological Conservation, London, 12 (2): 115-134.

POlLARD, E. 1979. A national scheme for monitoring the abundance of butterflies: the first three years. Proceedings of the Entomological Natural History Society, London, 12: 77-90.

Pollard, E.; D.O. Elias; M.J. Skelton \& J.A. Thomas. 1975. A method of assessing the abundance of butterflies in Monks Wood National Nature Reserve in 1973. Entomologist's Gazette, Oxon, 26: 79-88.

Ramos, R.R. \& A.V.L. Freitas. 1999. Population biology and wing color variation in Heliconius erato phyllis (Nymphalidae). Journal of the Lepidopterists Society, Los Angeles, 53 (1): 11-21.

Rio Grande do Sul. 1997. Plano de Manejo: Parque Estadual de Itapuã. Porto Alegre, Secretaria da Agricultura e Abastecimento, Departamento de Recursos Naturais Renováveis, $158 \mathrm{p}$.

SOUTHWOOD, T.R.E. 1978. Ecological methods with particular reference to the study of insect populations. London, Chapman \& Hall, $2^{\text {nd }}$ ed., 524p.

Summerville, K.S.; E.H. Metzler \& T.O. Crist. 2001. Diversity of Lepidoptera in Ohio forests at local and regional scales: how heterogeneous is the fauna. Annals of the Entomological Society of America, Ohio, 94 (4): 583-591.

Tyler, H.; K.S. Brown \& K. WiLson. 1994. Swallowtail Butterflies of the Americas. Florida, Scientific Publishers, 376p.

Vanini, F.; V. Bonato \& A.V.L. Freitas. 1999. Polyphenism and population biology of Eurema elathea (Pieridae) in a disturbed environment in tropical Brazil. Journal of the Lepidopterists Society, Los Angeles, 53 (4): 159-168.

WAechter, J.L. 1985. Aspectos ecológicos da vegetação da restinga no Rio Grande do Sul. Comunicações do Museu de Ciências da PUCRS, Série Botânica, Porto Alegre, 33: 49-68.

WAechter, J.L. \& J.A. JARenKow. 1998. Composição e estrutura do componente arbóreo nas matas turfosas do Taim, Rio Grande do Sul. Biotemas, Florianópolis, 11 (1): 45-69.

Walpole, M.J. \& I.R. Sheldon. 1999. Sampling butterflies in tropical rainforest: an evaluation of a transect walk method. Biological Conservation, Essex, 87 (1): 85-91.

WiLson, E.O. 1987. The little things that run the world: the importance and conservation of invertebrates. Conservation Biology, Boston, 1 (4): 344-346.

Wilson, E.O. 1997. Biodiversidade. Rio de Janeiro, Nova Fronteira, 700p.

Wood, B. \& M.P. Gillman. 1998. The effects of disturbance on forest butterflies using two methods of sampling in Trinidad. Biodivesity and Conservation, London, 7 (5): 597-616.

Received in 12.VII.2005; accepted in 02.V.2006. 